A prova pela fala. Sobre a causalidade em psicanálise Roland Gori

São Paulo, Escuta 1998

\title{
A prova pela fala
}

\section{Denise Teles Freire Campos}

A psicanálise, segundo Roland Gori, é uma experiência de "terceiro tipo", pois não somente devemos constatar que, assim como a física moderna, ela também inclui o observador dentro do dispositivo de mensuração, como, na sua particularidade, ela é um tipo de experiência em que o único instrumento de "mensuração" da verdade é a relação do observador com o observado. Assim também parece funcionar o estilo de escrita de Roland Gori. Ele não oferece suas teses e idéias de modo direto; ele vai traçando um caminho, quase que em "associação livre", um caminho de reconstrução da análise "continuada para além do tempo das sessões". A leitura do livro de Gori nos mostra que, assim como no interior do dispositivo analítico, também na escrita, leitor e escritor têm de fazer suas "provas". Antes de tudo, a prova é pela fala, pois a prática do psicanalista é a palavra, e fundamentalmente, a palavra que se atualiza na fala. Não há surpresa alguma quando Gori afirma que a situação analítica é uma situação específica de interlocução.

A força de A prova pela fala não se restringe ao impacto de seu título, mas, sobretudo, à originalidade de suas proposições e a uma referência constante e 
atualizada a Freud. O primeiro eixo de suas reflexões é centrado no capítulo II, onde ele situa a transferência no coração mesmo do dispositivo analítico. Nesse capítulo, ele retoma a noção de pensamentos de transferência. Trata-se de uma re-leitura de $A$ interpretação dos sonhos, de Freud, onde um tipo específico de pensamento vai operar de forma privilegiada permitindo a transferência. Enfim, os pensamentos de transferência são a possibilidade, mesmo que distorcida, mesmo que disfarçada, de manifestação do inconsciente. É por isso que Gori diz que, antes mesmo de ser transferência sobre o objeto, é transferência dentro da palavra, no sentido de que, mesmo antes de haver o objeto destinatário da transferência, há uma predisposição, ou talvez fosse mais correto dizer, uma função que possibilita que uma palavra seja, ao mesmo tempo, representação préconsciente e porta-voz do inconsciente, função que produz os "pensamentos de transferência". O alcance desta proposição é o de elevar o modelo do sonho ao estatuto de "paradigma" das formações inconscientes.

Os capítulos I, III e VI se articulam em torno deste eixo. Explicitando o modelo paradigmático do sonho e, no primeiro capítulo, Gori nos lembra que a situação analítica enquanto tal serve de "restos diurnos":

... a situação analítica oferece ao paciente os restos diurnos que o inconsciente precisa, pela "necessidade de transferência", para fazer retorno, quer dizer, para se revelar. $\mathrm{O}$ analista encarna de algum modo o ponto onde o pré-consciente cruza, através do jogo dos "pensamentos de transferência" e da idéia de transferência, com o inconsciente. $\mathrm{O}$ analista encarna esta presença e atualidade do inconsciente sem as quais não haveria análise. (p. 54)

$\mathrm{Na}$ situação particular que é a análise, a dinâmica transferênciacontratransferência, é o que vai marcar a especificidade da interlocução, das trocas subjetivas entre analisando e analista. Para Gori, a transferência é a "unidade epistemológica da prática e da teoria psicanalíticas". Tal é a importância da transferência que faz com que ambas, teoria e prática, não possam ser concebidas fora do dispositivo da psicanálise. Para ele, o dispositivo da análise é uma "escuta flutuante" na qual, pelo achatamento dos significantes, ele aceita temporariamente não dar nenhuma importância particular ao que escuta, deixando a verdade se refratar na superfície da linguagem pelo jogo das associações livres e de seu determinismo transferencial. É como se o analista "esvaziasse" a fala do paciente, esvaziasse os significantes, retirando seu significado predeterminado e se abrisse ao que ele vai chamar de "sonoridade" e a "anfibiologia das palavras". A conseqüência do funcionamento deste tipo de pensamento é que o trabalho de desvendamento do inconsciente tem que passar, obrigatoriamente, pelo préconsciente, conseqüentemente pela verbalização, pela atualização dos "pensamentos de transferência" em palavras, na fala. 
Os capítulos III e IV tratam de algumas conseqüências, históricas ou atuais, do primeiro eixo de reflexões sobre a transferência, em especial, quando Gori convida o psicanalista a se preservar de duas tentações sempre "reincidentes" na prática analítica: a primeira, de não estar atento aos "pensamentos de transferência", quer dizer, em última instância, não estar atento à transferência, e fazer sua leitura fora do dispositivo da análise; a segunda, de tentar escapar daquilo que o autor chama de "prova pela fala", agindo sob o efeito da transferência imediata ou da transferência narcísica, buscando um acesso direto ao inconsciente. Sobretudo no capítulo IV, ele repatria o acting out dizendo que é preciso distinguir claramente o acting out de fala, quando o paciente nos conta uma "passagem ao ato" através de um segundo ato - de fala, portanto transformando-o em material analítico - e aqueles que permanecem exteriores ao dispositivo, os "verdadeiros acting out são aqueles dos quais jamais ouvimos falar". Num estilo inusitado e, às vezes, provocante, Gori afirma que as revisões da teoria devem mais às paixōes transferenciais e aos seus acting out na fala e na escrita, do que se costuma confessar.

O segundo eixo de reflexões centrado no capítulo VII, se organiza em referência a uma concepção particular de "memória", uma memória concebida enquanto traição, pois a "recordação trai a memória nos dois sentidos do termo, manifesta e deforma-a. O esquecimento, longe de ser um avatar, um efeito secundário da lembrança, é a própria exigência estrutural". Gori nos alerta que Freud já havia insistido sobre o caráter falacioso e tendencioso da recordação, que fala da "natureza tendenciosa das nossas recordações. justamente onde nós suspeitávamos menos delas". A aptidão a se recordar, mesmo no processo de uma análise, é estritamente subordinada à paixão de esquecer. $\mathrm{O}$ recordar não é a memória. Não se trata do mesmo distrito psíquico.

$\mathrm{Na}$ análise temos acesso às "reminiscências", ao "compromisso". As reminiscências são detalhes, fragmentos ligados à representação recalcada, mas não são a lembrança exata daquilo que foi recalcado. Ora, o que vai aparecer na consciência é uma "formação inconsciente", resultante de um compromisso entre a reminiscência (receptáculo da representação recalcada) e a representação préconsciente. É neste sentido que, para Gori, é imperativo reconhecer que, na análise, não há necessidade de acesso; é lembrança exata do que foi recalcado, acesso à representação propriamente dita. Pois a memória, enquanto tal, é inacessível; o acesso é ao compromisso, à reminiscência, que atualiza o passado e o presente. Assim, utilizando-se das nuances da língua francesa, e deslizando, na língua portuguesa, entre a idéia de "reminiscência" e a de "memória", Gori obriga o tradutor a uma frase surpreendente: "recordamos para não lembrar".

O capítulo VI faz a passagem entre as reflexões acerca do ato analítico e aquelas referentes à concepção de memória; nele o autor nos provoca mais uma 
vez, afirmando que o texto "Moisés e o monoteísmo" é a "herança" que Freud vai deixar a todos os analistas como um convite a aprender a "renunciar ao sensível, ao material e ao visível".

Finalmente, no terceiro eixo do livro, tratado nos capítulos V e IX, o autor se dispõe à complexa discussão sobre o estatuto científico da teoria freudiana: a psicanálise é ciência ou somente ética? Para Gori, ela é um saber, submisso aos requisitos de uma epistemologia, que atualiza as exigências de uma ética, o resultado destas duas tendências é a definição da psicanálise como funcionamento de uma heurística dentro de uma prática: isto quer dizer que ela é o funcionamento de uma "teoria do sujeito inconsciente", que toma corpo, que se realiza (no sentido de que se torna verdadeira, se torna realidade) dentro do processo analítico.

Gori acrescenta que a psicanálise é um caso limite de ciência, dado o caráter "inconsciente" das verdades que ela produz, mas que ela funciona como, por exemplo, a história, ela é uma heurística. Trata-se de uma "ciência limite", posto que na prática psicanalítica as verdades produzidas e o dispositivo do tratamento não podem ser separados. $\mathrm{O}$ dispositivo mesmo da análise não é um instrumento de "descoberta da verdade" sobre o paciente, ou, ainda, sobre a subjetividade; ele é um dispositivo de produção de uma verdade que não poderia existir fora deste mesmo dispositivo. Assim sendo, a psicanálise é uma heurística aplicada a uma situação (dispositivo) específico. No sentido goriniano, a psicanálise não é uma teoria que se aplica ao sujeito, ou sobre ele, ela é um sistema explicativo que se cria com o sujeito.

Pode-se pensar que o autor "escolheu" deliberadamente um estilo de escrita em que, o significado do que é lido se cria como uma "construção" que atravessa também a história e a formação (mais lícito seria dizer "as formações", inclusive aquelas inconscientes) do psicanalista que lê. Não creio. Penso apenas que seu estilo é o resultado da tentativa de posicionar sua escrita na mesma região ontológica do seu objeto de trabalho cotidiano:

Todo evento analítico se produz em referência à transferência. A comunicação psicanalítica se nutre e se sustenta daquilo que ela toma por objetos, o inconsciente e a transferência; e aos quais ela fica submissa. A teoria somente se elabora dentro da transferência, ela deriva da auto-análise, da análise continuada para além do tempo das sessões, tanto dentro da prática do tratamento quanto dentro das construções metapsicológicas, ou, ainda, dentro das crises institucionais. 